\title{
Two new species of Licania (Chrysobalanaceae) from the Mata Atlantica of eastern Brazil
}

\section{Ghillean T. Prance ${ }^{1}$}

Summary. Recent collections have shown that material previously identified as Licania hoehnei Pilg. and L. spicata Hook. f. contain two previously undescribed species. The new species L. farinacea and L. areolata are described and illustrated and a key is given for all species of Licania sensu stricto of the forests of eastern Brazil.

Key Words. Atlantic coastal forests, Bahia, taxonomy.

\section{Introduction}

Since the publication of the last monograph of the Chrysobalanaceae (Prance \& Sothers 2003) a considerable number of new collections have been made, especially from eastern Brazil. This has made it possible to describe two new species of Licania, both of which I had noticed from single collections but concluded that more material was need to describe them. They belong to a small group of Licania with axillary rather than petiolar stipules including L. hoehnei Pilg., L. indurata Pilg. and L. spicata Hook. f., and much of the material cited below was previously identified by me as one of those species. A key is given below to all species of Licania from eastern Brazil that remain in the genus Licania after the recent separation into other genera of about half of the species formerly in Licania (Sothers et al. 2016).

\section{New species of Licania}

Licania farinacea Prance, sp. nov. Type: Brazil. Bahia: Municipio de Una, Reserva Biológico do Mico-leão, km 46 road Ilhéus to Una, $15^{\circ} 09^{\prime} \mathrm{S}, 39^{\circ} 05^{`} \mathrm{~W}, 26$ May 1993 (fl), André M. Amorim et al. 1281 (holotype CEPEC, isotype K).

http://www.ipni.org/urn:lsid:ipni.org:names:77165132-1

Trees to $20 \mathrm{~m}$ tall. The young branches sparsely appressedpuberulous, glabrescent, lenticellate. Leaves with stipules linear, $2 \mathrm{~mm}$ long, axillary or inserted on extreme base of petiole at junction with stem, early caducous; petioles 3 $5 \mathrm{~mm}$ long, puberulous, eglandular, shallowly canaliculate; lamina oblong to elliptic, coriaceous, $3.5-$ $10 \times 2-4.8 \mathrm{~cm}$, acuminate or apiculate at apex, the acumen $2-8 \mathrm{~mm}$ long, subcuneate to rounded at base, glabrous and shiny above, densely pale-brown pulverulentfarinaceous pubescent beneath (noted as pallid beneath when fresh in field notes); midrib plane and glabrous above slightly prominent and sparsely puberulous beneath; primary veins $6-7$ pairs, plane above, prominulous beneath; secondary venation smooth and inconspicuous. Inflorescence of terminal and subterminal racemose panicles, rachis and branches brown-puberulous. Bracts and bracteoles ovate-triangular. $0.5-1 \mathrm{~mm}$ long, tomentellous, persistent. Flowers $1.5-2 \mathrm{~mm}$ long, with short pedicels 0.2 - $0.4 \mathrm{~mm}$ long. Receptacle campanulate, grey tomentellous on exterior, tomentose within; calyx lobes triangular, acute, c. $0.4 \mathrm{~mm}$ long, tomentellous on exterior, sparsely tomentellous within. Petals absent. Stamens 5, unilateral, filaments glabrous, free to base, shorter than calyx lobes. Ovary inserted at base of receptacle, tomentose; style inserted at base of ovary pubescent almost to apex. Fruit pyriform, narrowed to a stipe $1 \mathrm{~cm}$ long and the swollen part to $4 \mathrm{~cm}$ long, $3.5 \mathrm{~cm}$ broad; exocarp with a dense rufous-velutinous pubescence; pericarp thin, hard, fibrous. Figs. 1, 2.

RECOGNITION. This species is close to Licania hoehnei Pilg., but differs in the farinaceous pubescence of the leaf underside, the smaller flowers and larger fruit and the shorter petioles.

HABITAT AND DISTRIBUTION. Atlantic coastal forest of Bahia, Brazil. Map 1.

\footnotetext{
Accepted for publication 14 August 2017. Published online 21 September 2017

1 Herbarium, Royal Botanic Gardens, Kew, Richmond, Surrey, TW9 3AE, UK. e-mail: siriain01@yahoo.co.uk
} 


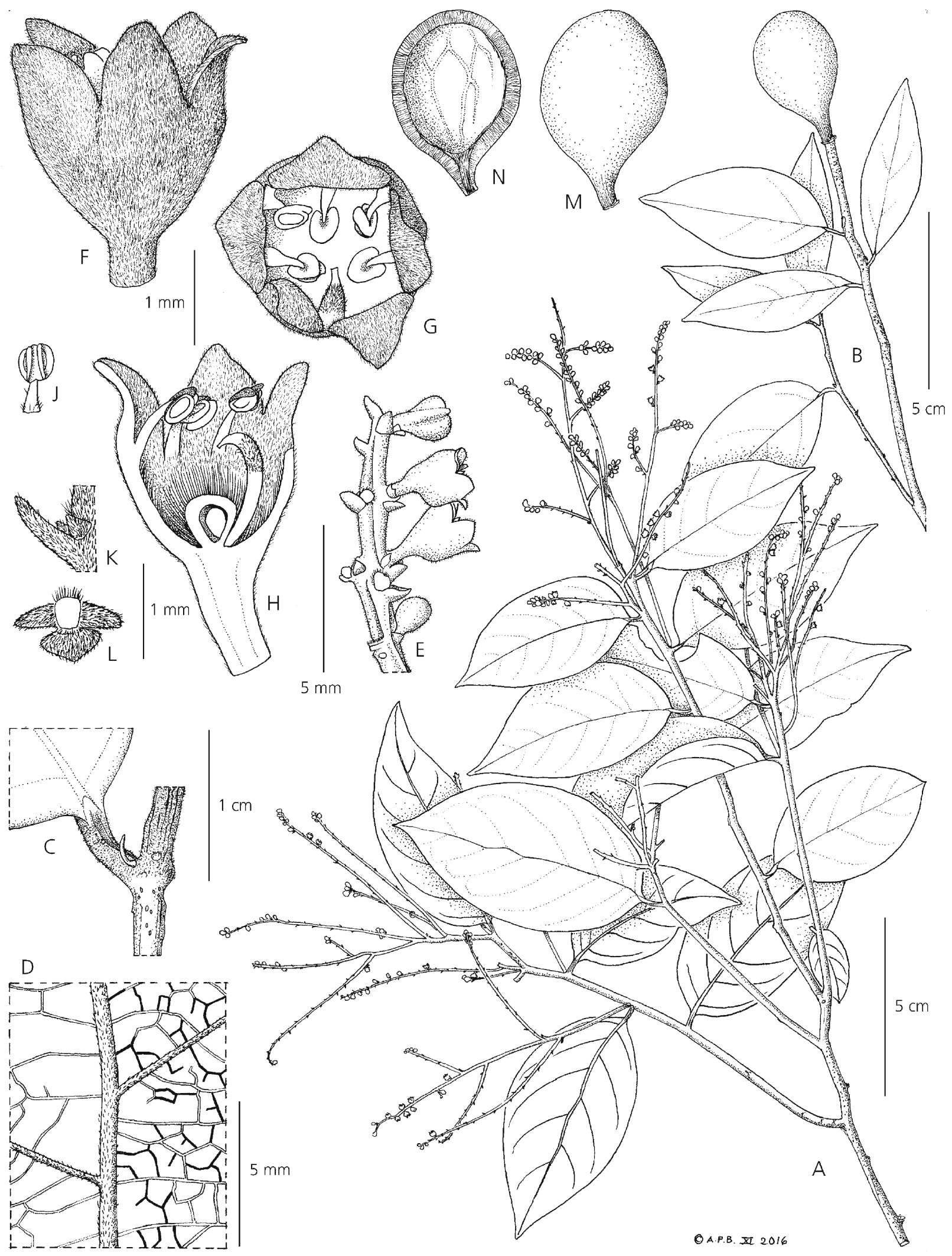

Fig. 1. Licania farinacea. A habit; B fruiting shoot with immature fruit; $C$ detail of petiole with stipule; D abaxial leaf surface with indumentum removed; $\mathrm{E}$ distal portion of inflorescence; $\mathrm{F}$ flower lateral view; $\mathrm{G}$ flower, face view; $\mathrm{H}$ flower longitudinal section along axis of symmetry; J inner face of stamen; $\mathrm{K}$ lateral view of floral bracts; $\mathrm{L}$ floral bracts from above; $\mathrm{M}$ mature fruit; $\mathrm{N}$ section of mature fruit. A, C - L from Amorim et al. 1281, B, M, N from Jardim et al. 193. DRAWN BY ANDREW BROWN. 


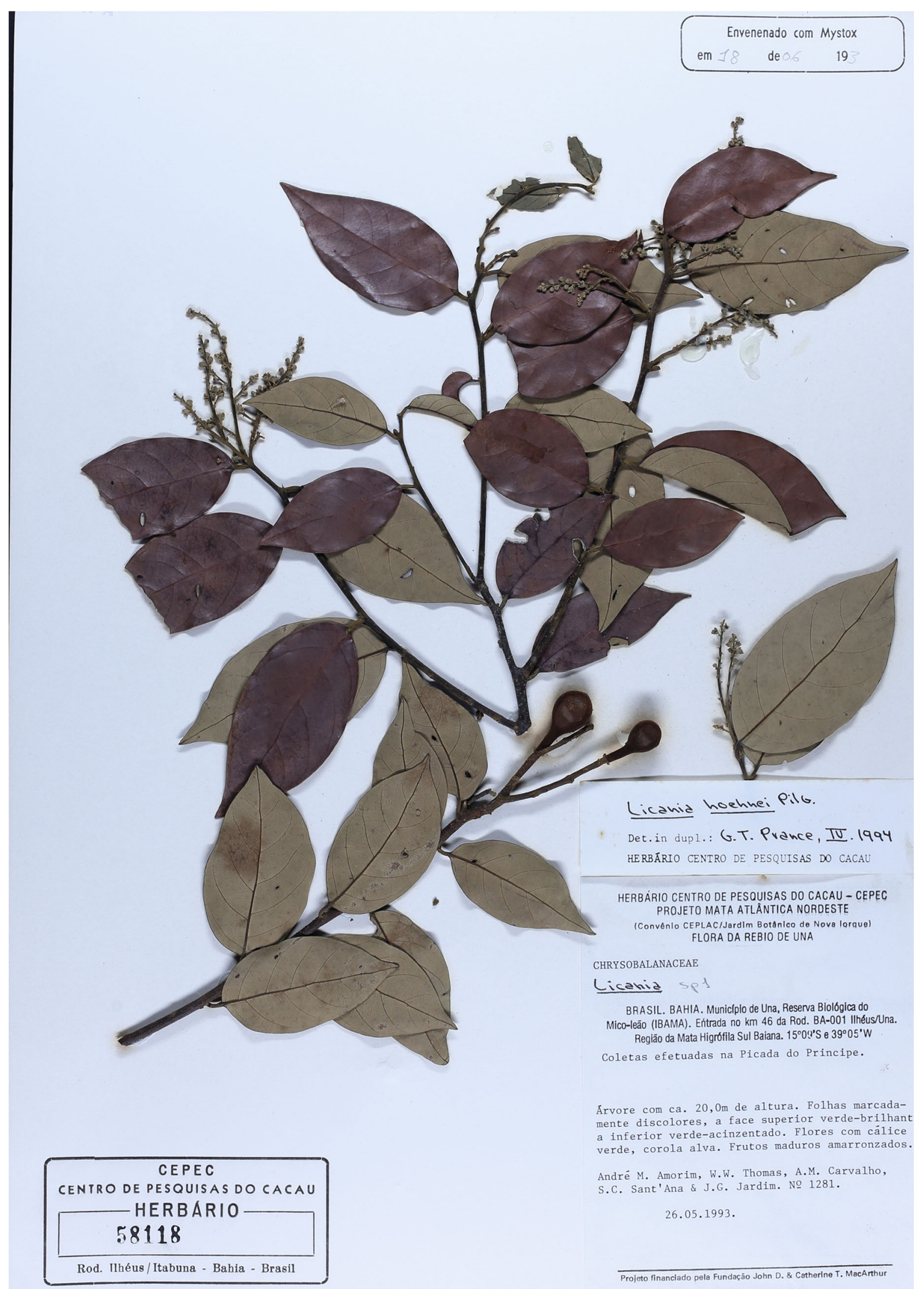

Fig. 2. Holotype of Licania farinacea Prance (Amorim 1281, courtesy of A. Amorim). 


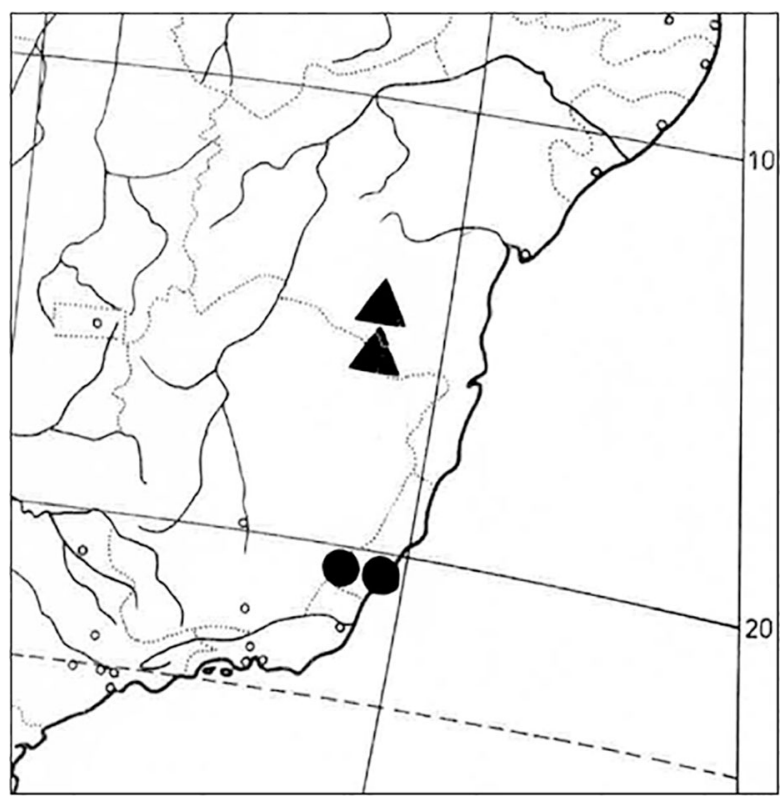

Map 1. Distribution of new species of Licania: L. farinacea Prance $\boldsymbol{\Delta}$; L. areolata Prance $\bullet$.

SPECIMENS EXAMINED: BRAZIL. Bahia: Município de Una, Reserva Biológico do Mico-leão, km 46 road Ilhéus to Una, $15^{\circ} 09^{\prime} \mathrm{S}, 39^{\circ} 05^{\prime} \mathrm{W}, 8$ - 12 March 1993 (fl), André M. Amorim et al. 1121 (CEPEC, K, NY); same locality, 8 - 12 March 1993 (fl), André M. Amorim et al. 1138 (CEPEC, K, NY); 26 May 1993 (fl), André M. Amorim et al. 1281 (holotype CEPEC, isotype K); 13 - 14 July 1993 (fr), J. G. Jardim et al. 183 (CEPEC, K, NY); 12 Oct. 1995 (st), André M. Amorim et al. 1733 (CEPEC, K, NY); 30 Aug. 1995 (fr), A. M. de Carvalho et al. 6079 (CEPEC, K, NY); Município de Itacaré, $6.7 \mathrm{~km} \mathrm{~S}$ of junction with BA 654, on road to Serra Grande, $6 \mathrm{~km} \mathrm{~W}$ of Itacaré, $14^{\circ} 15^{\prime} \mathrm{S}, 39^{\circ} 16^{\prime} \mathrm{W}, 2$ May 1993 (fl and young fr), W. Thomas, A. Amorim Eे J. Jardim 9790 (CEPEC, K, NY); Município de Ilhéus, $2 \mathrm{~km}$ NNE of Banco da Vitória road to Mata da Esperança, 28 Sept. 1994 (fr), W. Thomas et al. 10662 (CEPEC, K, NY); Ilhéus, Mata da Esperança, $2 \mathrm{~km}$ NNE do Banco da Vitória 1446'38"S, 3905'28"W, 12 March 1995 (fl), A. M. de Carvalho, F. Garcia Eै A. Furlan 5997 (CEPEC, K, NY).

PHENOLOGY. Flowering in March and April and fruiting July to September.

NOTE. I had put aside the collection Thomas 10662 as a new species with a note that more material was needed with flowers to describe it. There are now plenty of collections to describe this species, as cited above.
Licania areolata Prance, sp. nov. Type: Brazil. Espírito Santo: Município de Domingos Martins, Road BR-262, near Vitor Hugo, Rio Jucu, Braço Sul, 17 Jan. 1995 (fl), G. E M. Hatschbach 61607 (holotype K).

http:/ /www.ipni.org/urn:lsid:ipni.org:names:77165133-1

Trees to $25 \mathrm{~m}$ tall, the young branches sparsely puberulous, soon glabrous. Leaves with stipules axillary, ovate, $1 \mathrm{~mm}$ long, caducous; petioles $6-12 \mathrm{~mm}$ long, slightly canaliculate, eglandular; lamina oblong-elliptic, thinly coriaceous, $5-8.5 \times 1.5-3.5 \mathrm{~cm}$; finely acuminate at apex, the acumen $5-15 \mathrm{~mm}$ long, cuneate at base; glabrous above, lanate pubescent and deeply reticulate with stomatal cavities beneath; midrib slightly impressed above, prominent and sparsely puberulous beneath; primary veins $7-8$ plane or slightly impressed above, prominulous beneath. Inflorescence of terminal and subterminal racemose panicles, rachis and branches appressed tomentellous. Bracts and bracteoles minute, triangular c $1 \mathrm{~mm}$ long, tomentellous on exterior, almost glabrous within. Flowers c. $2 \mathrm{~mm}$ long, sessile. Receptacle campanulate-globular, grey tomentellous on exterior, tomentose within; calyx lobes triangular, acute, $0.4 \mathrm{~mm}$ long, tomentellous on both surfaces. Petals absent. Stamens 5, unilateral, filaments shorter than calyx lobes. Ovary inserted at base, of receptacle, tomentose; style inserted at base of ovary sparse puberulous. Fruit orbicular and slightly narrowed towards peduncle, $4.5 \times$ $4.5 \mathrm{~cm}$, exocarp velvety rufous-brown. Fig. 3 .

RECOGNItION. Close to Licania hoehnei Pilg. and L. farinacea Prance, but differs in the deeply reticulate leaf undersurface with stomatal cavities, the impressed midrib on the leaf upper surface and the larger fruit.

HABITAT AND DISTRIBUTION. Atlantic rainforest of Espírito Santo, Brazil. Map 1.

SPECIMENS EXAMINED: BRAZIL. Espírito Santo, Município Venda Nova do Imigrante: Alto Bananal, 900 m, 15 Jan. 1995 (fl), G. E $\mathcal{F}^{2}$ M. Hatchbach 61510 (holotype, K); Município de Santa Maria de Jetibá, $5 \mathrm{~km}$ from Santa Maria de Jetibá, 20²'43.5"S, 4041'46"W, 12 Dec. 2004 (fr), R. N. C. Teixeira, I. R. Lopes Ẽ M. M. M. Lopes 116 (K); Município de Santa Maria de Jetibá, $2 \mathrm{~km}$ from Santa Maria de Jetibá, 20¹'35.5"S, 4042'27.2"W, 24 Sept. 2005 (fr), R. N. C. Teixeira, G. Mascarenhas Eै V. M. Moura 189 (K).

PHENOLOGY. Collected in flower in January. 


\section{Key to species of Licania from Eastern Brazil}

1. Leaf lower surface glabrous.

2. Leaf acuminate at apex, cuneate at base, membraneous; receptacle urceolate . . . . . L. glazioviana

2. Leaf rounded to obtuse at apex, rounded to cordate at base; receptacle campanulate . . L. littoralis

1. Leaf lower surface pubescent or with hair-filled stomatal cavities.

3. Flowers in small cymules on long slender secondary branches less than $0.5 \mathrm{~mm}$ thick.

4. Flowers c. $6 \mathrm{~mm}$ long; stipules $7-10 \mathrm{~mm}$ long; leaf lower surface with hair-filled stomatal

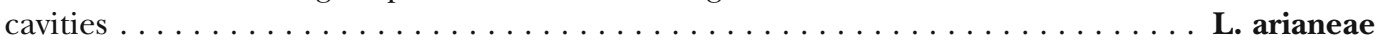

4. Flowers $2-4 \mathrm{~mm}$ long; stipules $1-3 \mathrm{~mm}$ long; leaf lower surface lanate, farinaceous or with stomatal cavities.

5. Leaf lower surface with hair-filled stomatal cavities; petioles $8-10 \mathrm{~mm}$ long; leaf apex

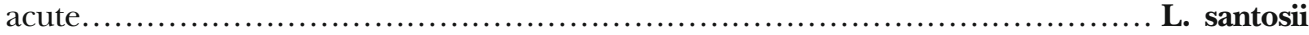

5. Leaf lower surface grey-farinaceous pubescent without cavities; petioles $1.5-6 \mathrm{~mm}$; leaf apex rounded or acuminate

6. Leaves coriaceous, apex rounded; fruit globose. . . . . . . . . . . . . . cymosa

6. Leaves chartaceous, apex acuminate; fruit pyriform. . . . . . . . . . . L. hypoleuca

3. Flowers sessile or subsessile on primary branches of inflorescence.

7. Leaf lower surface with hair-filled stomatal cavities.

8. Stipules 11 - $13 \mathrm{~mm}$ long, navicular; petioles $8-12 \mathrm{~mm}$ long flowers $6-7.5 \mathrm{~mm}$ long. L. naviculistipula

8. Stipules 1.5 - $2 \mathrm{~mm}$ long, linear; petioles 3 - $10 \mathrm{~mm}$ long; flowers $2-5 \mathrm{~mm}$ long.

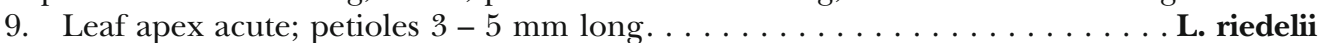

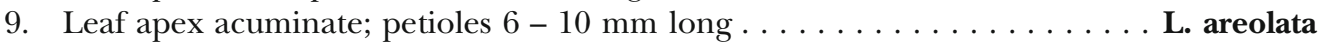

7. Leaf lower surface lanate or pulverulent pubescent, but without stomatal cavities.

10. Leaf lower surface pulverulent farinaceous.

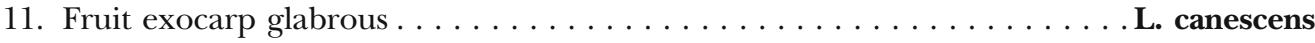

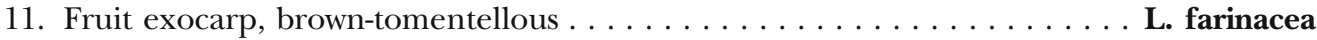

10. Leaf lower surface lanate pubescent.

12. Stipules persistent and adnate to base of petiole.

13. Exterior of flowers and inflorescence grey-puberulous not forming a complete covering . . . . . . . . . . . . . . . . . . . . kunthiana

13. Exterior of flowers densely tomentellous or tomentose with surfaces completely covered.

14. Leaf apex acuminate to caudate

15. Leaf lower surface brown pubescent . . . . . . . . . . L. micrantha

15. Leaf lower surface white-pubescent . . . . . . . . . . . . L. nitida

14. Leaf apex apiculate, lower surface grey pubescent . . . . . . . L. bahiensis 12. Stipules axillary and usually caducous.

16. Leaves $12-15 \times 6-8.5 \mathrm{~cm}$, apex apiculate . . . . . . . . lamentanda

16. Leaves $3-9.5 \times 1-4.5 \mathrm{~cm}$, apex usually acuminate or rounded in L. hoehnei.

17. Inflorescence mainly of axillary unbranched spikes; leaves finely acuminate

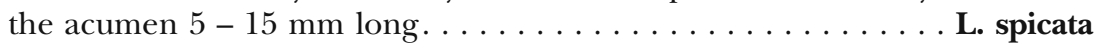

17. Inflorescence of racemose panicles, mainly terminal; leaves rounded or bluntly acuminate at apex

18. Petioles $10-12 \mathrm{~mm}$ long, leaves $5-9.5 \times 2.6-4.5 \mathrm{~cm} \ldots \ldots$. L. belemii

18. Petioles $4-8 \mathrm{~mm}$ long; leaves $3-8 \times 1.5-3 \mathrm{~cm}$.

19. Leaf apex rounded to acute . . . . . . . . . L. hoehnei

19. Leaf apex with acumen to $11 \mathrm{~mm}$ long. . . . . . . . L. indurata 


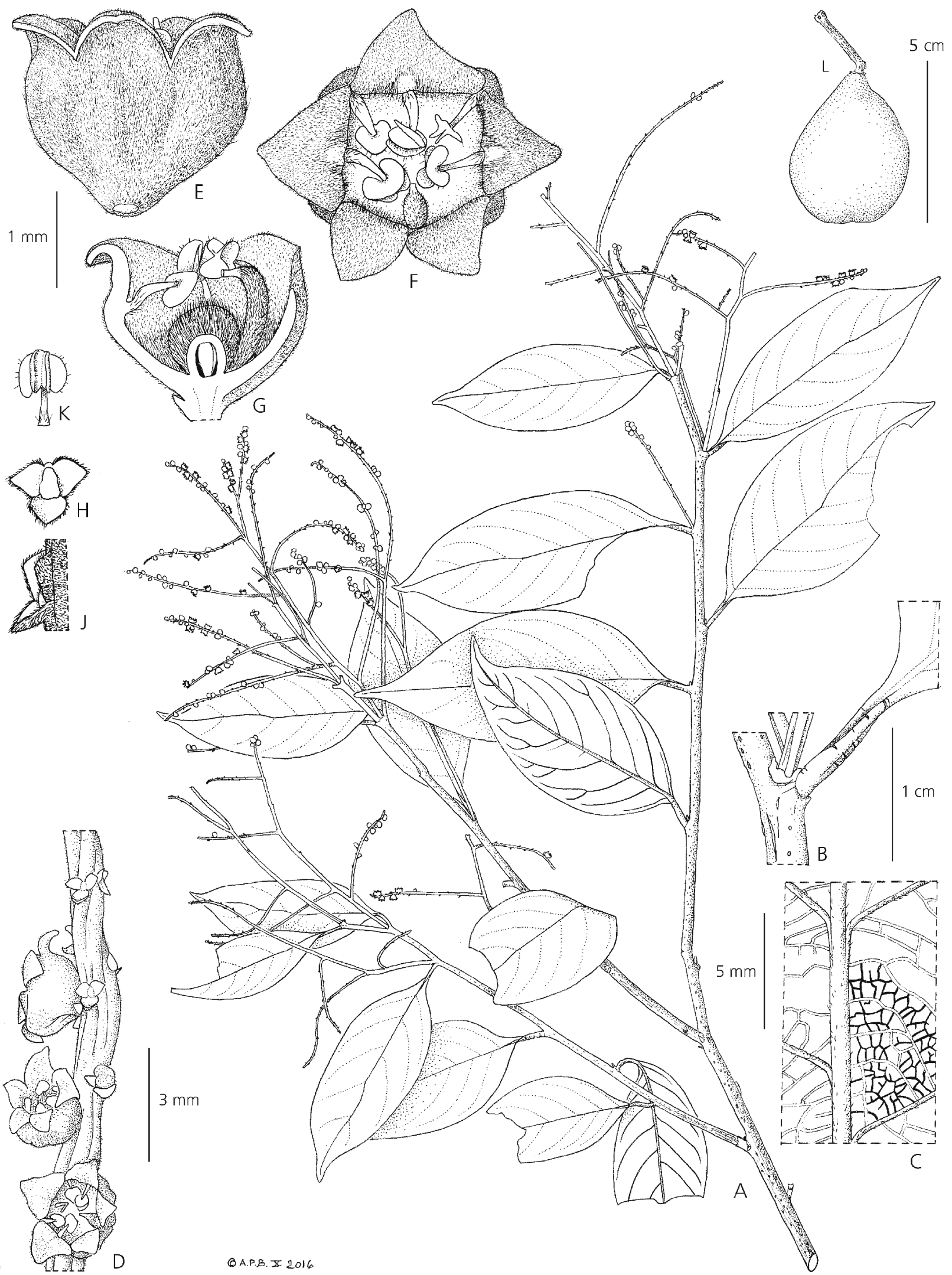

Fig. 3. Licania areolata. A habit; B petiole; $C$ abaxial surface of leaf showing reticulate, areolate venation; $D$ enlargement of part of inflorescence; $E$ lateral view of flower; $\mathrm{F}$ view of flower from above; $\mathrm{G}$ flower section; $\mathrm{H}$ bracteoles from above; $J$ lateral view of bracteoles; K stamen; L fruit. A - K from Hatschbach et al. 61607, L from Teixeira et al. 189. DRAWN BY ANDREW BROWN. 


\section{Acknowledgements}

I thank Andrew Brown for the drawings and Cynthia Sothers for collaboration with the taxonomy of Licania.

Open Access This article is distributed under the terms of the Creative Commons Attribution 4.0 International License (http://creativecommons.org/ licenses/by/4.0/), which permits unrestricted use, distribution, and reproduction in any medium, provided you give appropriate credit to the original author(s) and the source, provide a link to the Creative Commons license, and indicate if changes were made.

\section{References}

Prance, G. T. \& Sothers, C. A. (2003). In: A. E. Orchard \& A. J. G. Wilson (eds), Chrysobalanaceae 1: Chrysobalanus to Parinari. Species Plantarum: Flora of the World Part 9: 1 - 319. Published for the Species Plantarum Steering Committee of the International Organization for Plant Information by ABRS, Canberra.

Sothers, C. A., Prance, G. T. \& Chase, M. (2016). Towards a monophyletic Licania: a new generic classification of the polyphyletic Neotropical genus Licania (Chrysobalanaceae). Kew Bull. 71: art. 58 pp. $1-68$. 